\title{
STRES KERJA DAN COPING DALAM MEMEDIASI KONFLIK PERAN TERHADAP SUBJECTIVE WELL BEING
}

\author{
Putu Yudari Pratiwi \\ pyudairy@gmail.com \\ Desak Ketut Sintaasih \\ Putu Saroyeni Piatrini \\ Program Magister Manajemen \\ Program Pasca Sarjana Fakultas Ekonomi dan Bisnis Universitas Udayana
}

\begin{abstract}
The development of female workers in Indonesia especially in Bali is increasing.Previous study found when women decide to work will threat their well being. On the other hand well being can increase when woman work in service industry such as a nurse. The purpose of this study is to describe the influence of role conflict, work stress, and coping on female nurse subjective well being and to know the role of work stress and coping on mediating effect role conflict to subjective well beingSample are 115 nurses in Puri Raharja hospital, using stratified random sampling method. Data analysis techniques using PLS (Partial Least Square).The results showed that 1) role conflict has a negative and significant effect on subjective well being. 2) Role conflict has no significant effect on job stress. 3) Role conflict has a negative and significant effect on problem focused coping. 4) Work stress has no significant effect on subjective well being. 5) Coping has a positive and significanteffect on subjective well being. 6) Coping can mediate the influence of role conflict on subjective well being.
\end{abstract}

Key words: subjective well being, role conflict, work stress, coping, nurse

\begin{abstract}
ABSTRAK
Perkembangan pekerja wanita di Indonesia khususnya di Bali kian meningkat. Penelitian sebelumnya menyebutkan bahwa ada ancaman pada well being ketika wanita memutuskan untuk bekerja. Namun, well being dikatakan dapat meningkat pada pekerjaan tertentu khususnya pekerjaan dalam pelayanan seperti perawat. Tujuan penelitian ini adalah untuk menjelaskan pengaruh konflik peran, stres kerja, dan coping terhadap subjective well being perawat wanita. Penelitian ini juga menguji peran stres kerja dan coping dalam memediasi konflik peran terhadap subjective well being. Penelitian dilakukan di RSU Puri Raharja, dengan sampel para perawat wanita. Pemilihan sampel menggunakan metode stratified random sampling, dan responden penelitian sebanyak 115 orang. Teknik analisis data menggunakan PLS (Partial Least Square). Hasil penelitian menunjukkan bahwa 1) Konflik peran berpengaruh negatif dan signifikan terhadap subjective well being. 2) Konflik peran tidak berpengaruh signifikan terhadap stres kerja. 3) Konflik peran berpengaruh negatif signifikan terhadap problem coping. 4) Stres kerja tidak berpengaruh signifkan terhadap subjective well being. 5) Coping berpengaruh positif signifikan terhadap subjective well being. 6) Coping terbukti mampu memediasi pengaruh konflik peran terhadap subjective well being.
\end{abstract}

Kata kunci : subjective well being, konflik peran, stres kerja, coping, perawat

\section{PENDAHULUAN}

Perkembangan pekerja wanita di Indonesia khususnya di Bali kian meningkat. Keberadaan kebijakan-kebijakan yang mengutamakan wanita, alasan-alasan individual, serta gelombang pekerja wanita dari kalangan muda yang mulai bekerja, memacu peningkatan jumlah partisipasi angkatan kerja wanita secara reguler. Ada beberapa alasan wanita bekerja, yaitu: untuk meningkatkan kualitas hidup, meningkatkan status sosial, mengurangi ketergantungan 
pada suami, dan membayar hutang (Nilakusumawati dan Susilawati, 2011). Di tengah peningkatan jumlah pekerja wanita, International Labour Organization (2014) mencatat bahwa, di Indonesia masih terjadi perbedaan jumlah angkatan kerja laki-laki dan perempuan, yakni, pekerja laki-laki $62,5 \%$ dan pekerja perempuan $37,5 \%$ atau sekitar 5 berbanding 3. Kondisi ini juga disebutkan dalam Peraturan Menteri Pemberdayaan Perempuan dan Perlindungan Anak atau PPPA (2015), bahwa lebih rendahnya persentase pekerja perempuan, karena masih adanya perlakuan kekerasan, perlakuan diskriminatif untuk mencapai posisi karir tertentu, jam kerja yang tidak menentu, dan adanya pemotongan pajak lebih besar, karena perempuan selalu dianggap berstatus lajang.

Upaya untuk meningkatkan jumlah tenaga kerja wanita telah gencar dilakukan, namun masih banyak para wanita tidak menggunakan kesempatan ini untuk bersaing di dunia kerja (Peraturan Menteri PPPA, 2015). Masih banyaknya wanita memilih untuk tidak bekerja, karena beberapa faktor yang mempengaruhi, salah satunya adalah persepsi akan well being.

Wanita pekerja umumnya memiliki well being yang lebih lebih rendah dibandingkan wanita sebagai ibu rumah tangga. Hal ini disebabkan oleh kondisi kerja yang tidak kondusif serta tuntutan tanggung jawab terhadap keluarga yang besar, sehingga mengurangi intensitas subjective well being pekerja wanita (Lennon, 1994). Selain itu, wanita yang bekerja juga dianggap tidak memiliki kontrol akan diri sendiri dan lingkungan, serta rendahnya otonomi diri, sehingga menyebabkan rendahnya subjective well being. Subjective well being merupakan kesejahteraan individu yang mengukur ke dalam diri atau intrapersonalnya (Keyes, 2005).

Penelitian lain menemukan hal yang sebaliknya, bahwa kecenderungan subjective well being dari pekerja wanita yang sudah menikah dan memiliki anak, lebih rendah dibandingkan yang masih lajang, akibat ketidakmampuan mereka mencapai karir yang lebih tinggi, karena harus mengurus keluarga (Erlandsson dan Eklund, 2006), namun, Elgar dan Chester (2007), menyebutkan hal yang berbeda, bahwa, wanita yang bekerja cenderung memiliki fungsi psikologis yang baik. Wanita yang bekerja penuh waktu memiliki subjective well being yang lebih baik, memiliki perasaan bahagia dan kondisi mental yang baik, dibandingan dengan wanita yang hanya menjadi ibu rumah tangga. Hal ini dapat terjadi, karena pekerjaan yang dilakukan dan tanggung jawab pada pekerjaan berkorelasi positif dan signifikan dengan subjective well being wanita yang bekerja (Erlandsson dan Eklund, 2006; Srimathi dan Kumar, 2010). Hal yang senada juga disebutkan Taylor et al. (2009:448), bahwa, karir yang berhubungan dengan sifat alaminya untuk merawat (nurture), seperti guru atau perawat, ternyata memberikan kesejahteraan psikologis pada wanita tersebut. Penelitian tersebut juga menemukan bahwa well being perawat cenderung tinggi pada keseluruhan dimensi. Perawat dipandang memiliki kemampuan menjalin hubungan positif dengan orang lain, sehingga meningkatkan subjective well being mereka. Penelitian lainnya juga menegaskan bahwa pekerjaan yang berhubungan dengan pelayanan dan perawatan terhadap orang lain yang mendapatkan kesembuhan, mampu memberikan kepuasaan tersendiri bagi diri perawat dan mampu meningkatkan kesejahteraan dirinya (Papalia et al., 2009).

Adanya hasil yang berbeda tentang subjective well being pekerja wanita seperti diuraikan sebelumnya, menarik untuk dikaji lebih lanjut bagaimana hal tersebut pada pekerja wanita yang bekerja pada dunia kesehatan, khususnya perawat. Penelitian dilakukan pada salah satu rumah sakit di Denpasar, yaitu Rumah Sakit Umum (RSU) Puri Raharja. Alasan memilih rumah sakit ini dikarenakan, hasil wawancara awal dengan beberapa perawat menunjukkan adanya masalah subjective well being, seperti yang diungkap pada pemaparan sebelumnya. Selain itu RSU Puri Raharja memiliki kinerja 
pelayanan dengan rata-rata baik di kelasnya yaitu kelas C. Pada tahun 2015 RSU Puri Raharja berada pada urutan ke tiga dengan nilai kinerja rumah sakit terbaik di kelasnya. Kinerja pelayanan yang baik tentunya menuntut seluruh karyawan, termasuk perawat bekerja semaksimal mungkin untuk menghasilkan kinerja pelayanan yang baik, ramah, dan tulus dalam merawat pasien. Hal ini tentunya meningkatkan tuntutan, beban kerja dan stres kerja bagi perawat.

Riset pendahuluan yang dilakukan dengan mewawancarai beberapa orang perawat menunjukkan hanya 16,7 persen mempersepsikan mereka memiliki well being yang baik karena difasilitasi oleh organisasi, seperti otonomi diri, pertumbuhan diri, dan adanya kesempatan untuk berkembang. Sementara sisanya, 73,3 persen, merasa adanya hambatan dan tantangan dalam mencapai prestasi kerja. Alasan utama yang dikemukakan adalah kesulitan dalam membagi waktu antara karir, pekerjaan, dan kegiatan sosial. Para perawat memiliki persepsi bahwa mereka mengalami kesulitan dalam membagi waktu, perhatian, dan fokus ketika dihadapkan pada peran-peran pekerjaan, keluarga, dan peran sosial. Hal ini cenderung memicu konflik peran bagi diri perawat.

Adanya fenomena yang terjadi pada pekerja wanita tentang subjective well being dan hasil-hasil studi empiris yang beragam, mengindikasikan bahwa ada beberapa faktor yang dapat mempengaruhi subjective well being seorang pekerja, khusunya pekerja wanita. Seperti Bourgault et al. (2015), menyebutkan bahwa perawat dianggap sebagai salah satu kunci pelayanan bagi rumah sakit, sehingga perawat dituntut tanggung jawab tinggi, profesional dalam jam kerja dan high risk, yang cenderung mempengaruhi subjective well being. Hal ini cenderung menyumbang stres kerja juga tinggi bagi perawat wanita. Tuntutan kerja dan waktu kerja yang padatpun juga akan meningkatkan intensitas konflik peran (Churiyah, 2007), sehingga mempengaruhi kesejahteraan psikologisnya.
Konflik peran menimbulkan hubungan yang tumpang tindih antara peran-peran tersebut $(\mathrm{Xu}, 2009)$. Konflik peran menjadi salah satu sumber stres dari banyak pekerja (Powell dan Greenhaus, 2006). Peran yang dihadapi perawat bukan hanya tentang peran pekerjaan dan keluarga, namun juga antara peran pekerjaan dan peran sosial. Hal ini bisa saja terjadi di wilayah yang memang memiliki ikatan kuat terhadap sosialnya seperti di Bali. Budaya kolektivisme yang kental memberikan tanggung jawab bagi individu mengambil bagian dalam peran sosial sebagai suatu keharusan. Tidak terkecuali wanita Bali yang secara peraturan adat harus mengambil bagian dalam masyarakat (Sudantra, 2011).

Penelitian Vallone dan Donaldson (2001) juga menyebutkan konflik peran ganda antara pekerjaan dan keluarga secara signifikan dapat memprediksi subjective well being. Konflik peran ini memberikan efek baik dalam jangka pendek ataupun jangka panjang pada subjective well being karyawan secara keseluruhan. Penelitian Panatik et al. (2011) juga menemukan bahwa konflik peran pekerjaan dan keluarga ternyata mempengaruhi pengalaman subjective well being pekerja baik saat di rumah ataupun dalam pekerjaan. Penelitian ini juga menemukan bahwa pemicu konflik peran yang terjadi meningkatkan intensitas stress yang akhirnya mempengaruhi subjective well being dari karyawan. Intensitas distress yang tinggi akan cenderung menurunkan subjective well being pekerja. Stres memicu munculnya perilaku disfungsi sehingga menganggu kesehatan secara fisik dan kesehatan mental dalam bentuk rendahnya subjective well being (Malek et al., 2010; Yunuset al., 2011; Bell et al.,2012). Pekerja wanita yang memiliki ketidakseimbangan peran dilaporkan akan lebih sering mengalami stres, sakit kepala, tekanan darah yang tinggi, dan penambahan berat badan (Ul-Ain et al., 2013; Delina dan Raya,2013). Menurut Taylor et al. (2009:550), konflik peran dapat dikurangi atau diatasi jika individu memiliki kemampuan adaptasi masalah atau coping yang baik sehingga 
mampu meningkatkan kembali subjective well being. Coping didefinisikan sebagai kesatuan kognitif, afektif, perilaku, dan proses psikologis yang secara sadar ataupun tidak sadar digunakan untuk mengatasi masalah ataupun stressor yang terjadi (Vashchenko $e t$ al., 2007). Coping terdiri dari dua dimensi yaitu Emotion focused merupakan coping yang berfokus pada keadaan emosi internal pada individu.

Problem focused coping adalah bagaimana menghadapi stressor yang ada dengan aksi langsung (Folkman, 1984). Wanita yang mampu mengontrol kehidupan mereka menggunakan bentuk-bentuk coping aktif jauh lebih memiliki subjective well being yang baik daripada yang tidak (Varma dan Dhawan, 2006; Srimathi dan Kumar, 2010). Sebagaimana juga disebutkan bahwa coping berpengaruh langsung terhadap subjective well being (Fierro dan Jimenez, 2002; Elfering et al., 2005; Rodriguez et al., 2015; Picken, 2012).

Berdasarkan fenomena yang diamati dan hasil-hasil studi empiris yang telah diuraikan, penelitian ini fokus pada pekerja wanita di bidang kesehatan, yaitu perawat untuk mengeksplorasi hubungan antara konflik peran, subjective well being, coping, dan stres kerja. Dalam penelitian juga mengkaji apakah stres kerja dan coping memediasi hubungan antara konflik peran dan subjective well being, yang mana pada penelitianpenelitian sebelumnya belum terungkap secara jelas.

Adapun tujuan penelitian ini adalah: 1) menjelaskan pengaruh konflik peran terhadap subjective well being; 2) Menguji pengaruh stres kerja terhadap subjective well being; 3) Menguji pengaruh coping terhadap subjective well being; 4) Menganalisis pengaruh konflik peran terhadap stres kerja; 5) Menjelaskan pengaruh konflik peran terhadap coping; 6) Menguji peran stres kerja dalam memediasi hubungan konflik peran dengan subjective well being; dan 7) Menguji peran coping dalam memediasi hubungan konflik peran dengan subjective well being.

\section{TINJAUAN TEORETIS}

\section{Peran Wanita dalam Masyarakat}

Gender adalah elemen dasar dari konsep diri (Taylor et al., 2009:425). Gender memberikan pengaruh mengenai bagaimana peranan laki-laki dan wanita dalam masyarakat. Perkembangan gender memberikan perspektif secara biologis yang menyatakan bahwa feminimitas dan maskulinitas secara tegas berbeda, bahwa perempuan haruslah feminim dan laki-laki haruslah maskulin. Hal ini juga berhubungan dengan kekuasaan atau power yang dimiliki. Konsep gender yaitu feminim dan maskulin yang sederhana memberikan label kepada laki-laki dan wanita mengenai peran apa yang harus mereka lakukan dalam masyarakat. Konsep ini memberikan anggapan bahwa wanita haruslah berada di rumah untuk mengurusi seluruh urusan rumah tangga. Wanita hanya menjalankan peran sebagai pengasuh keluarga dengan bekerja sepanjang waktu di dalam rumah dibandingkan dengan bekerja di luar rumah (Taylor et al., 2009)

Hal ini sejalan dengan penelitian Munthe (2003) yang melihat perkembangan peranan wanita sejak abad 11 sampai dengan abad 20, dimana peranan wanita dibagi dalam dua kategori yaitu passive women dan active woman. Passive women berlangsung sampai dengan akhir tahun 1830. Pada masa ini peranan wanita hanya seputar mengurus rumah tangga. Wanita dididik untuk menjadi ibu rumah tangga yang baik. Active woman di mulai di tahun 1830 setelah banyaknya perjuangan dari kelompokkelompok pejuang peran wanita. Perkembangan peran wanita pun mulai bergeser di akhir abad ke 20. Wanita sudah memasuki dunia kerja. Wanita dewasa di Amerika mulai memasuki angkatan kerja dan bekerja sepanjang hayatnya. Namun peran wanita bekerja tidak serta merta dapat sejajar dengan laki-laki karena wanita masih bekerja dan terkonsentrasi pada bidang yang sesuai dengan anggapan gender feminitas mereka (Taylor et al., 2009).

Hal ini juga terjadi di Indonesia, yang mana pada awalnya, peranan wanita hanya 
sebatas dalam rumah tangga dan mengurus anak. Pada awal abad 20 peranan wanita akhirnya beralih untuk bekerja. Awalnya, anak perempuan hanya diberikan pendidikan tentang rumah tangga, beralih diberikan kesempatan untuk bersekolah dan memilih pekerjaan sesuai dengan keinginan. Dalam pekerjaan kini mereka tidak hanya bekerja dalam bidang pengasuhan, namun sudah bekerja untuk menduduki posisi yang dimonopoli laki-laki seperti angkatan bersenjata, bisnis, pemimpin perusahaan atau organisasi,dan masuk dalam anggota legislatif (Munthe, 2003). Hal ini juga didukung kebijakan-kebijakan pemerintah yang mendukung wanita untuk setara dengan laki-laki di dunia kerja (Peraturan Menteri PPPAK, 2015).

\section{Peran Wanita Bali dalam Masyarakat}

Perkembangan peran wanita dalam masyarakat juga terjadi di Bali. Dalam lingkungan masyarakat Bali, wanita tidak hanya bertanggung jawab pada keluarga sebagai ibu rumah tangga, namun juga bertanggung jawab terhadap peran sosial, khususnya terkait dengan kegiatan adat. Hal ini terjadi, salah satunya dikarenakan masyarakat Bali menganut sistem patrilineal, sehingga wanita dianggap memiliki derajat yang lebih rendah dibandingkan laki-laki (Yufiza, 2010). Selain itu, adanya prinsip sistem kekeluargaan purusa, dimana keluarga laki-laki memiliki hak penuh pada anak dan memiliki hubungan hukum kekeluargaan pada anak tersebut, sedangkan tidak pada keluarga wanita (Sudantra, 2011) .

Bagi masyarakat Bali, khususnya Hin$\mathrm{du}$, ada tradisi dan adat istiadat yang harus diikuti termasuk di dalamnya bertanggung jawab untuk wajib ikut serta pada seluruh kegiatan sosial dan adat yang ada di lingkungannya. Sejak remaja, para wanita Bali sudah dibiasakan bagaimana mereka seharusnya berada dalam lingkungan sosial, sehingga mereka tidak hanya belajar secara formal di sekolah, namun juga belajar secara informal untuk memenuhi tanggung jawab secara sosial (Sudantra, 2011).
Setelah menikah dan berkeluarga, kewajiban wanita Bali bertambah. Mereka harus mulai mengurus keluarga, suami dan mengambil peran sebagai anggota sosial masyarakat adat. Setiap desa adat di Bali mengharuskan wanita yang sudah menikah untuk mengambil peran adat. Peran adat yang dimaksud mulai dari kegiatan-kegiatan seperti upacara kelahiran bayi, pernikahan, kematian, dan kegiatan-kegiatan keagamaan lain yang dilakukan di rumah tetangga ataupun di pura di lingkungan wilayah tempat tinggalnya (Paramartha, 2015).

Di sisi lain, pada saat ini wanita Bali juga mengikuti perkembangan wanita secara global, dengan mengambil peran sebagai wanita pekerja. Nilakusumawati dan Susilawati (2011) menyebutkan Wanita Bali banyak yang bekerja untuk meningkatkan kualitas hidup, meningkatkan status sosial, mengurangi ketergantungan pada suami dan membantu ekonomi keluarga.

\section{Subjective Well Being}

Well being diidentifikasikan sebagai fungsi psikologi positif untuk menyatakan individu memiliki kesehatan mental yang baik (Ryff dan Keyes, 1995). Keyes (2005) juga menyatakan Subjective well being merupakan kesejahteraan individu yang mengukur ke dalam diri atau intrapersonalnya. Subjective well being adalah kebahagiaan yang dideskripsikan sebagai fase positif dari pemikiran yang memberikan dampaknya kepada pengalaman kehidupan secara menyeluruh. Well being merupakan turunan dari pemenuhan pribadi, bentuk ekspresi, aktualisasi diri, dan determinasi diri (Page dan Brodrick, 2009). Diener (2009:12) mendefinisikan subjective well being adalah keinginan yang berkualitas sebagai bentuk penilaian positif seseorang terhadap kehidupannya secara menyeluruh. Dimensi Subjective well being terdiri dari 6 dimensi antara lain: Self acceptance (penerimaan diri), Positive relations with other (hubungan yang baik dengan orang lain), Autonomy (otonomi), Environmental mastery (penguasaan terhadap lingkungan), Purpose in life (tujuan 
hidup), dan Personal growth (pertumbuhan diri) (Ryff dan Keyes,1995).

Beberapa penelitian menjelaskan hubungan antara wanita menikah yang bekerja dengan kesejahteraan fungsi-fungsi psikologis. Lennon (1994), menyebutkan wanita menikah yang memilih bekerja, dianggap mendapatkan penghargaan dari pekerjaan yang dilakukan setiap hari, sehingga mampu meningkatkan control personal dan meningkatkan subjective well being. Disisi lain, penelitian tentang wanita menikah yang bekerja, akan merasa memiliki role identity yang kuat yang berpengaruh pada pandangan terhadap diri mereka sehingga meningkatkan subjective well being (Elgar dan Chester, 2007). Pekerjaan yang dilakukan dan tanggung jawab pada pekerjaan dianggap berkorelasi positif dan signifikan terhadap subjective well being wanita yang bekerja (Sahu dan Rath, 2003; Erlandsson dan Eklund, 2006; Srimathi dan Kumar, 2010).

\section{Hubungan Konflik Peran, Stres kerja, dan Coping dengan Subjective Well Being}

Konflik peran terjadi ketika individu berada pada dua atau lebih peran yang mengharuskannya menjalankan peran tersebut secara bersamaan. Konflik peran disebut pula sebagai interrole conflict yaitu konflik peran yang terjadi ketika individu dihadapkan pada dua atau lebih posisi atau peran yang harapan atas peran-peran tersebut bertentangan (Luthans, 2006). Powell dan Greenhaus (2006) menyebutkan, bahwa konflik peran terdiri atas tiga dimensi, yaitu time based conflict, strain based conflict, dan behavior based conflict. Peran yang dihadapi wanita bukan hanya tentang peran pekerjaan dan keluarga, namun juga antara peran pekerjaan dan peran sosial di masyarakat. Hal ini bisa saja terjadi di wilayah yang memang memiliki ikatan kuat terhadap lingkungan sosialnya, seperti yang terjadi di daerah Bali. Budaya kolektivisme yang kental memberikan tanggung jawab bagi individu mengambil bagian dalam peran sosial sebagai suatu keharusan. Tidak ter- kecuali wanita Bali yang menurut peraturan adat harus mengambil bagian dalam masyarakat (Sudantra, 2011). Adanya konflik peran ini ternyata mempengaruhi bagaimana subjective well being wanita. Beberapa penelitian menyebutkan bahwa konflik peran dapat memicu rendahnya well being yang dimiliki individu (Panatik et al.,2011; Koyuncu et al.,2012; Sianturi dan Zulkarnain, 2013). Berdasarkan hasil studi empiris tersebut, hipotesis penelitian ini adalah:

$\mathrm{H}_{1}$ : konflik peran berpengaruh negatif dan signifikan terhadap subjective well being

Stres kerja adalah respon dari fisik maupun emosional individu yang muncul ketika individu tidak mampu mengatasi tuntutan dan kebutuhan dari pekerjaan yang dilakukan (Alves, 2005). Luthans (2006) menjelaskan, stres kerja sebagai suatu interaksi individu dengan lingkungan kerja yang dihubungkan dengan respon-respon adaptif terhadap tuntutan fisik maupun psikologis pada individu secara berlebihan. Menurut Leung et al. (2007), ada 6 dimensi dari stres kerja, yaitu perilaku individu, dukungan sosial, konflik peran, lingkungan kerja, beban kerja, dan situasi rumah dan pekerjaan. Beberapa penelitian menunjukkan bahwa stres kerja yang dialami individu memicu munculnya perilaku disfungsional, sehingga menganggu kesehatan secara fisik dan mental dalam bentuk rendahnya subjective well being. Malek et al. (2010) menunjukkan adanya hubungan negatif dan signifikan antara stres dan well being pada para pemadam kebakaran baik di Malaysia ataupun Amerika. Yunus et al. (2011) juga menemukan bahwa stres kerja yang dialami di tempat kerja dan perilaku-perilaku disfungsi menyebabkan kesehatan fisik yang buruk sampai dengan well being yang rendah. Bell et al. (2012) dalam penelitiannya menyatakan bahwa stres kerja, kesehatan individu dan keseimbangan dari kehidupan kerja dan pribadi saling berhubungan untuk menciptakan dan meningkatkan kesejahteraan hidup atau well being. Sementara Kurnia (2015), menyebutkan para pekerja di Jakarta yang 
mengalami stres karena faktor peran, otonomi, dan dukungan sejawat berpengaruh negatif dan siginifikan terhadap well being mereka.

Berdasarkan hasil-hasil studi empiris tersebut, maka dapat dirumuskan hipotesis sebagai berikut:

$\mathrm{H}_{2}$ : Stres kerja berpengaruh negatif dan signifikan terhadap subjective well being

Coping merupakan proses untuk menata tuntutan yang dianggap membebani atau melebihi kemampuan sumber daya (Taylor et al., 2009:550). Vashchenko et al. (2007) mendefinisikan coping sebagai kesatuan kognitif, afektif, perilaku dan proses psikologis yang secara sadar ataupun tidak sadar digunakan untuk mengatasi stres yang terjadi. Dimensi coping terdiri atas emotion focused coping (EFC) dan problem focused coping (PFC) (Folkman, 1984). Bagaimana coping dilakukan individu, ternyata berdampak terhadap subjective well being. Beberapa penelitian menunjukkan bahwa strategi coping berdampak pada peningatan intensitas well being.

Carver et al. (1989) menemukan bahwa coping aktif (problem coping) yaitu coping yang langsung mengatasi permasalahan, lebih berhasil dalam memberikan dampak positif danlebih adaptif, baik untuk kesehatan mental maupun well being, sedangkan coping pasif seperti menjauhi konfrontrasi, menghindari perilaku yang biasanya atau menolak adanya masalah, lebih rendah keberhasilannya. Hal ini juga ditemukan oleh Fierro dan Jimenez (2002), yang melihat adanya hubungan antara coping dengan well being pada mahasiswa baru. Secara lebih detail Williams dan McGillicuddy-De Lisi (2000) menyebutkan bahwa problem focused coping lebih tinggi hubungannya dengan well being dibandingkan dengan emotion focused coping, dan berpengaruh lebih rendah terhadap well being, baik pada wanita maupun laki-laki. Hal ini juga ditegaskan oleh Picken (2012), bahwa strategi coping dapat berdampak pada penyesuaian diri serta well being pada tahanan laki-laki di penjara, dimana emotion focused atau passive lebih rendah hubungannya dengan well being. Barron et al. (2002) juga menemukan hal yang sejalan, bahwa problem focused coping berkorelasi positif dan signifikan terhadap well being. Begitu juga dengan Semmer, 2003 (dalam Elfering et al., 2005) menemukan bahwa well being memiliki hubungan positif dengan problem focused coping. Atas dasar temuan studi-studi tersebut, maka dirumuskan hipotesis 3 sebagai berikut:

$\mathrm{H}_{3}$ : Coping berpengaruh positif dan signifikan terhadap subjective well being

Konflik peran yang dirasakan juga cenderung menyumbang stres kerja. Alves (2005) menyebutkan bahwa stres kerja adalah respon dari fisik maupun emosional individu yang muncul ketika individu tidak mampu mengatasi tuntutan dan kebutuhan dari pekerjaan yang dilakukan. Stres kerja juga sebagai suatu interaksi individu dengan lingkungan kerja yang dihubungkan dengan respon-respon adaptif terhadap tuntutan fisik maupun psikologis pada individu secara berlebihan (Luthans, 2006). Beberapa penelitian menunjukkan bahwa konflik peran memicu tingginya intensitas stres yang dirasakan individu yang bekerja (Jamadin et al., 2005; Delina dan Raya, 2013; Ul-Ain et al., 2013). Semakin tinggi konflik peran yang dialami seseorang, maka semakin tinggi pula tingkat stresnya. Atas dasar bukti empiris tersebut maka dapat dirumuskan hipotesis penelitian ini sebagai berikut:

$\mathrm{H}_{4}$ : Konflik peran berpengaruh positif dan signifikan terhadap stres kerja

Konflik peran sebenarnya dapat diredam dengan memiliki adaptasi pada masalah atau coping yang baik dari individu. Hal ini ditunjukkan oleh Taylor et al. (2009: 550), bahwa proses terjadinya coping dipicu dengan adanya konflik yang dialami individu termasuk dalam hal ini adalah konflik peran, sehingga dapat dikatakan memicu coping tersebut muncul. Selain itu konflik peran juga mempengaruhi gaya coping yang di- 
gunakan sehingga konflik peran memiliki korelasi yang signifikan terhadap coping (Vashchenko et al. 2007; Aazami et al., 2015). Berdasarkan penelitian terdahulu, maka hipotesis penelitian ini menjadi:

$\mathrm{H}_{5}$ : Konflik peran berpengaruh negatif dan signifikan terhadap coping

\section{Peran stres kerja dalam memediasi hubu- ngan konflik peran dengan subjective well being}

Beberapa penelitian terdahulu menemukan ada hubungan antara konflik peran dan subjective well being (Panatik et al., 2011; Koyuncu et al., 2012; Sianturi dan Zulkarnain, 2013). Penelitian lainnya menunjukkan adanya pengaruh konflik peran terhadap stres (Delina dan Raya, 2013; Ul-Ain et al., 2013). Sementara adanya hubungan antara stres kerja dengan subjective well being ditunjukkan dalam penelitian Malek et al. (2010), Yunus et al. (2011), Bell et al. (2012), dan Kurnia (2015). Hasil studi empiris terdahulu juga menyebutkan bahwa konflik peran pekerjaan dan keluarga ternyata mempengaruhi pengalaman well being karyawan, baik saat di rumah maupun di tempat kerja. Penelitian ini juga menemukan bahwa pemicu konflik peran yang terjadi meningkatkan intensitas distres yang akhirnya mempengaruhi well being dari karyawan (Kinnunen dan Mauno, 1998).

Adanya hubungan-hubungan antar konflik peran dan stres kerja (Delina dan Raya, 2013; Ul-Ain et al., 2013), serta konflik peran dan subjective well being (Panatik et al., 2011; Koyuncu et al., 2012; Sianturi dan Zulkarnain, 2013), serta stres kerja dan subjective well being (Malek et al., 2010; Yunus et al., 2011; Bell et al., 2012; Kurnia, 2015), maka diajukan hipotesis penelitian ini sebagai berikut:

$\mathrm{H}_{6}$ : Stres memediasi hubungan konflik peran dengan subjective well being

\section{Peran coping dalam memediasi hubungan} konflik peran dengan subjectivewell being

Sesuai dengan konsep coping, Taylor et al. (2009: 550) menemukan bahwa proses terjadinya coping berada di antara konfik dan kualitas hidup atau well being. Hal ini mendasari keinginan untuk melihat bagaimana coping mampu meningkatkan well being dengan menurunkan pengaruh konflik peran pada well being. Selain konsep coping di atas adanya hubungan antara konflik peran dan subjective well being (Panatik et al., 2011; Koyuncu et al., 2012; Sianturi dan Zulkarnain, 2013) dan pengaruh konflik peran terhadap coping (Vashchenko et al., 2007; Taylor et al., 2009; Aazami et al., 2015), serta coping berpengaruh terhadap subjective well being (Van Harreveld et al., 2007; Picken, 2012; Rodriguez et al., 2015), memperkuat konsep coping yang ada. Lo et al. (2003) menyebutkan bahwa tingginya role conflict yang dialami wanita yang sudah menikah di Hongkong, lebih memerlukan strategi coping yang tepat, sehingga sapat meningkatkan tujuan hidup ataupun harapan-harapan yang dimiliki, walaupun ketika sudah menikah dan memiliki anak. Penelitian Aazami et al. (2015) juga menemukan coping menjadi mediasi antara work family conflict untuk mengurangi tekanan psikologis dan meningkatkan kebahagiaan secara psikologis. Atas dasar hasil-hasil studi empiris tersebut maka diajukan hipotesis penelitian sebagai berikut:

$\mathrm{H}_{7}$ : Coping memediasi hubungan konflik peran dengan subjective well being

\section{Rerangka Konseptual}

Berdasarkan riset awal yang ada ditemukan beberapa faktor yang mempengaruhi subjective well being wanita yang bekerja. Yang pertama adalah konflik peran secara signifikan dapat memprediksi subjective well being. Konflik peran ini memberikan efek baik dalam jangka pendek ataupun jangka panjang pada subjective well being karyawan secara keseluruhan (Kinnunen dan Mauno, 1998; Vallone dan Donaldson, 2001). Kedua adalah stres kerja. Intensitas distress yang tinggi akan cenderung menurunkan subjective well being pekerja. Stres memicu munculnya perilaku disfungsi sehingga menganggu kesehatan secar fisik dan 
kesehatan mental dalam bentuk rendahnya subjective well being (Kinnunen dan Mauno, 1998; Malek et al., 2010; Yunus et al., 2011). Yang ketiga adalah coping. Wanita yang mampu mengontrol kehidupan mereka menggunakan bentuk-bentuk coping aktif jauh lebih memiliki subjective well being yang baik daripada yang tidak. (Varma dan Dhawan, 2006; Srimathi dan Kumar, 2010). Sehingga berdasarkan pemaparan sebelumnya maka kerangka konseptual dapat digambarkan sebagai berikut:

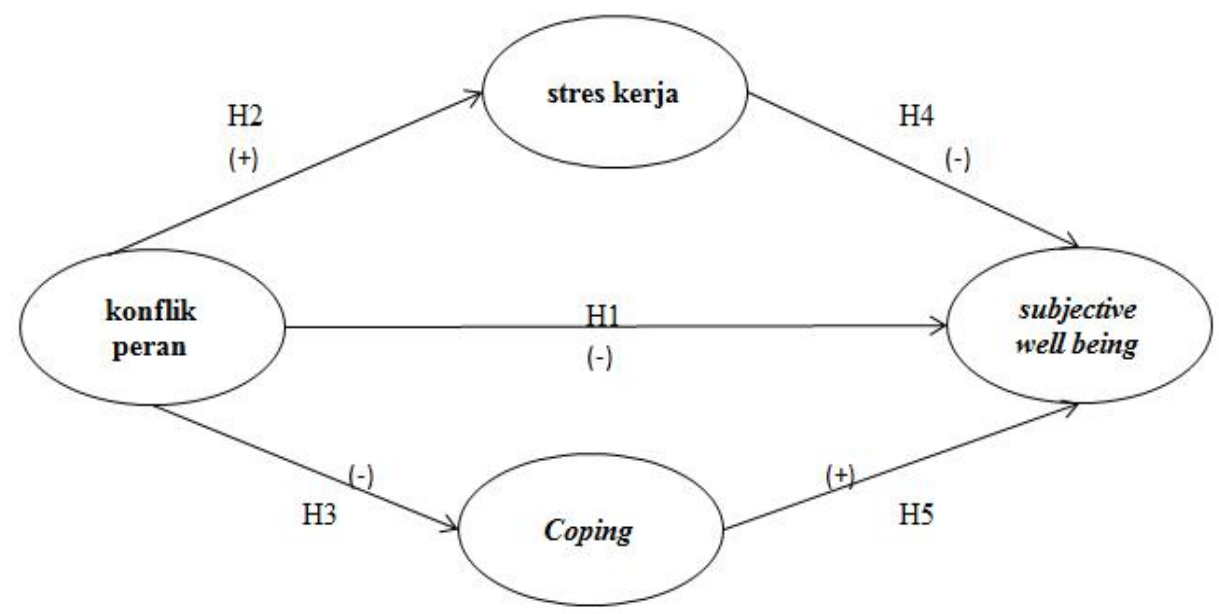

Gambar 1

Rerangka Konseptual Penelitian

\section{METODE PENELITIAN}

\section{Rancangan Penelitian}

Penelitian ini menggunakan pendekatan eksplanatory research dengan penelitian bersifat kausalitas, yang bertujuan untuk menganalisis pengaruh konflik peran terhadap subjective well being pada perawat RSU Puri Raharja. Penelitian ini juga menganalisis peran stres kerja dan coping dalam memediasi pengaruh konflik peran terhadap subjective well being.

\section{Populasi dan Sampel}

Populasi penelitian adalah seluruh perawat wanita yang bekerja di RSU Puri Raharja, berjumlah 161 orang. Teknik pengambilan sampel menggunakan teknik proportional random sampling. Jumlah sampel ditentukan dengan menggunakan rumus Slovin, yaitu: $\mathrm{n}=\mathrm{N} /\left(\mathrm{N}\left(\mathrm{d}^{2}\right)+1\right)$. Berdasarkan rumus tersebut, $\mathrm{n}=161 /\left(161\left(0,05^{2}\right)+1\right)=$ $114,795=115$ orang (pembulatan). Dalam pengumpulan data digunakan instrumen penelitian dalam bentuk kuesioner, yang telah diuji validitas dan reliabilitasnya.

\section{Variabel Penelitian}

Berdasarkan rumusan masalah dan kerangka konseptual, variabel penelitian diindentifikasi sebagai variabel eksogen dan endogen. Variabel eksogen yaitu konflik peran $(\mathrm{KP})$, dan variabel endogen meliputi: stres kerja (SK), coping (CO), dan subjective well being (SWB).

\section{Definisi Operasional Variabel}

Konflik Peran (KP) yaitu konflik yang terjadi pada individu yang bekerja dalam hal ini adalah perawat, ketika dihadapkan pada dua atau lebih peran dan tanggung jawab sekaligus yaitu tanggung jawab pekerjaan, tanggung jawab keluarga, dan tanggung jawab sosial. Peran dan tanggung jawab tersebut harus dijalankan secara bersamaan walaupun peran tersebut bisa saja bertentangan satu sama lain (Yang et al., 2000). Konflik peran diukur dalam dua dimensi yaitu: 1) konflik antara pekerjaan dengan keluarga, yaitu bagaimana tanggung jawab akan pekerjaan dan tanggung jawab pada 
keluarga, diukur dengan time based conflict, strain based conflict, dan behavior based conflict; 2) konflik antara pekerjaan dan sosial yaitu tanggung jawab terhadap pekerjaan dan kegiatan sosial dalam masyarakat yang dapat menimbulkan konflik peran, dilihat dari time based conflict, strain based conflict, dan behavior based conflict.

Stres Kerja (SK) adalah kondisi individu dalam hal ini perawat ketika dituntut atau dibebankan tanggung jawab yang melebihi kapasitasnya, baik dari diri individu ataupun dari organisasi, sehingga menyebabkan individu mengalami perubahan secara psikologis. Stres kerja diukur dalam 5 dimensi (Leung et al., 2007) yaitu: 1) Perilaku individu, 2) dukungan sosial, 3) situasi rumah, sosial, dan pekerjaan 4) beban kerja, dan 5) Lingkungan kerja.

Coping (CO) didefinisikan sebagai proses individu baik kognitif, perilaku, dan psikologis dalam menanggapi stresor ataupun masalah yang menganggu diri dengan cara berfokus pada masalah atau stresor yang dihadapi. Coping diharapkan membantu individu untuk kembali pada kondisi awal dan perbaikan kualitas hidup. Coping dalam penelitian ini terdiri dari dua dimensi (Folkman, 1984) yaitu emotion focused coping dan problem focused coping. Subjective Well Being (SWB) yaitu penilaian positif individu, dalam hal ini perawat, terhadap kehidupannya yang dinilai berdasarkan respon kognitif dan respon emosional, sehingga memberikan kesejahteraan dan kebahagiaan psikologis pada kehidupannya. Subjective well being diukur dari enam dimensi (Ryff dan Keyes, 1995), yaitu: 1) penerimaan diri, 2) hubungan positif dengan orang lain, 3) autonomi, 4) penguasaan lingkungan, 5) tujuan hidup, 6) pertumbuhan diri.

\section{Teknik Analisis Data}

Teknik analisis data yang digunakan dalam penelitian ini meliputi statistik deskriptif dan statistik inferensial. Analisis statistik deskriptif digunakan untuk mendeskripsikan karaktersistik responden dan variabel penelitian. Statistik deskriptif yang digunakan adalah distibusi frekuensi untuk mendeskripsikan variabel berdasarkan jawaban responden atas tiap item pertanyaan dalam kuesioner, dilihat dari nilai rata-rata skor. Statistik inferensial yang digunakan adalah analisis SEM (Structural Equation Modelling) berbasis component atau variance yaitu PLS (Partial Least Square).

\section{ANALISIS DAN PEMBAHASAN Karakteristik Responden}

Dengan memperhatikan karakteristik responden berdasarkan usia, ternyata sebagian besar responden 63 persen berusia antara 31-40 tahun. Sisanya, 29 persen memiliki usia antara 20-30 tahun, dan hanya 8 persen berusia 40 tahun ke atas. Hal ini menunjukkan bahwa para perawat rumah sakit ini sebagian besar berada pada tahap usia dewasa tengah. Dilihat dari pendidikan mereka, sebagian besar adalah lulusan diploma 86 persen dan sisanya, 14 persen berpendidikan sarjana. Data tersebut memberi gambaran, bahwa para perawat ini memiliki pendidikan yang cukup tinggi untuk mengemban tugas dan tanggung jawab pada RSU Puri Raharja.

Berdasarkan masa kerja, sebagian besar responden ternyata memiliki masa kerja di atas 10 tahun sebanyak 63 persen, responden dengan masa kerja 0-5 tahun sebanyak 30 persen, dan terakhir responden dengan masa kerja 6-10 tahun sebanyak 7 persen. Hal ini menunjukkan bahwa sebagian besar dari responden sudah bekerja lama di instansi RSU Puri Raharja. Berdasarkan persepsi responden akan keaktifan mereka dalam mengikuti kegiatan sosial ditemukan bahwa sebagian besar dari responden yaitu sebesar 72,2 persen aktif melakukan kegiatan sosial baik itu kegiatan gotong royong, PKK, banjar dan kegiatan sosial lainnya, sedangkan sisanya sebesar 27,8 persen, mengaku tidak aktif melakukan kegiatan sosial. Hal ini dapat dikatakan bahwa sebagian besar responden aktif mengambil peran dan tanggung jawab dalam lingkungan sosialnya. 


\section{Analisis Inferensial}

Teknik analisis data yang digunakan dalam penelitian ini adalah PLS. Dari hasil pengolahan data diperoleh model empirik penelitian seperti tersaji pada Gambar 2 berikut ini. Berdasarkan hasil tersebut, selajutnya dievaluasi model pengukuran (outer model), untuk mengetahui validitas dan reliabilitas indikator-indikator yang mengukur variabel laten dan evaluasi model struktural (inner model) untuk mengetahui ketepatan model dan pengujian hipotesis penelitian.

\section{Evaluasi Model Pengukuran (Outer Model)}

Pengujian outer model dilihat dari tiga kriteria yaitu discriminant validity, convergent validity, dan composite reliability. Berikut pada Tabel 1 disajikan hasil pengujian ketiga kriteria tersebut. Dari informasi yang tersaji pada Tabel 1, dapat dijelaskan bahwa dimensi dari masing-masing variabel memiliki nilai loading factor di atas 0,60 , sehingga dapat dinyatakan bahwa seluruh dimensi valid dalam merefleksikan atau mengukur variabel latennya, sehingga dapat diartikan bawa seluruh variabel memiliki convergent validity yang baik. Dilihat dari nilai AVE juga nampak nilai AVE seluruh variabel laten atau konstruk di atas 0,50 sehingga dapat dikatakan keseluruhan variabel laten memiliki dicriminant validity yang baik.

Pengujian reabilitas konstruk dilihat dari dua kriteria yaitu nilai composite reability dan cronbach alpha. Informasi pada Tabel 1 menunjukkan nilai composite reability dan cronbach alpha di atas 0,70, sehingga dapat dikatakan bahwa seluruh variabel adalah reliabel (Ghozali dan Latan, 2015).

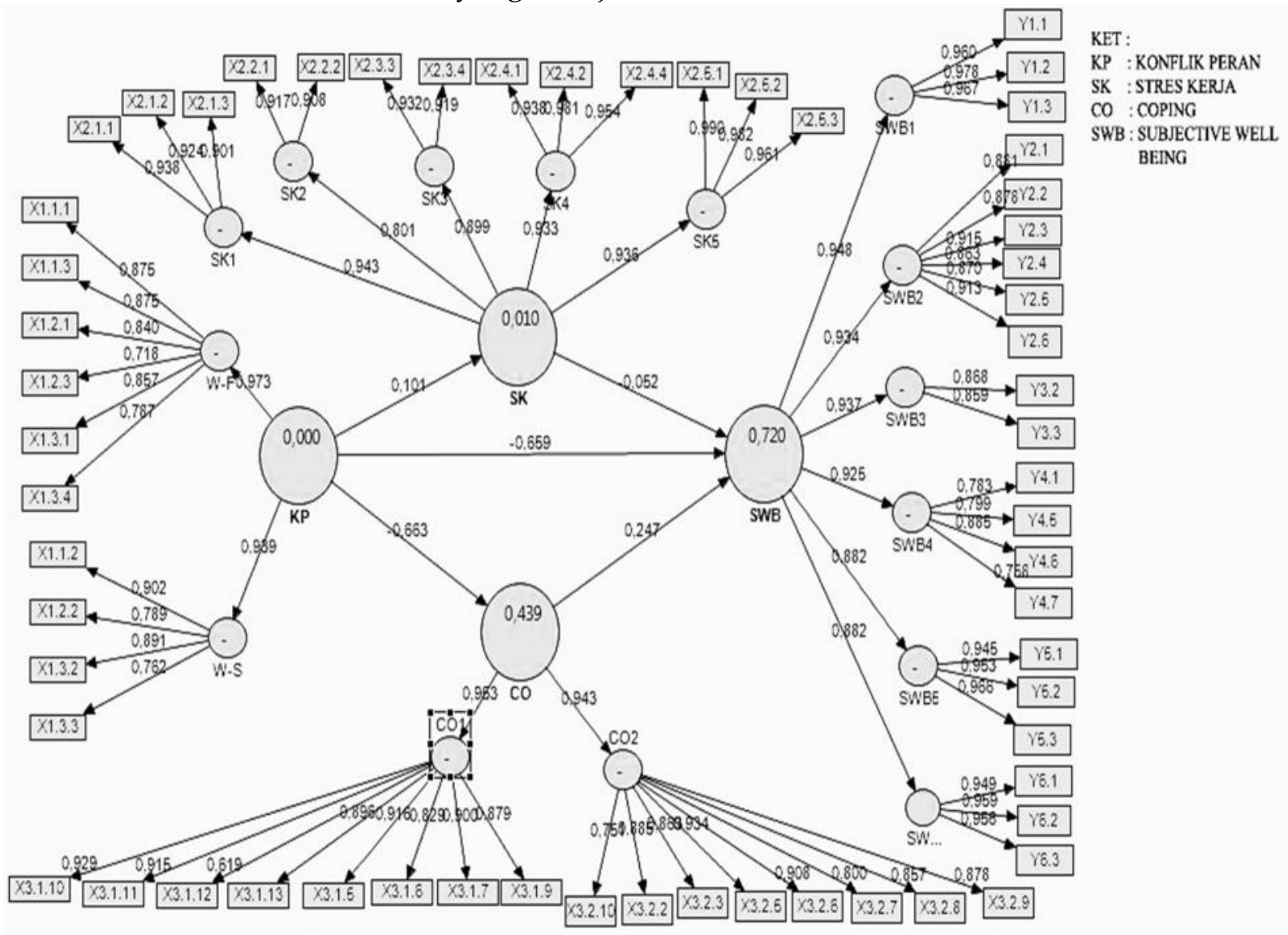

Gambar 2

Model Empirik Penelitian

Tabel 1

Uji Validitas dan Reliabilitas 


\begin{tabular}{|c|c|c|c|c|}
\hline Variabel dan Indikator & $\begin{array}{c}\text { Outer } \\
\text { Loadings*) }\end{array}$ & $\left.A V E^{* *}\right)$ & $\begin{array}{c}\text { Composite } \\
\text { Reliability**) }\end{array}$ & $\begin{array}{l}\text { Cronbach } \\
\text { Alpha**) }\end{array}$ \\
\hline \multicolumn{5}{|l|}{ Konflik Peran $\left(X_{1}\right)$} \\
\hline Work-Family conflict $\left(\mathrm{X}_{1}\right)$ & 0,973 & 0,633 & 0,945 & 0,927 \\
\hline Work-Social Conflict $\left(\mathrm{X}_{2}\right)$ & 0,939 & & & \\
\hline \multicolumn{5}{|l|}{ Stres Kerja $\left(Y_{1}\right)$} \\
\hline Perilaku individu $\left(\mathrm{Y}_{1.1}\right)$ & 0,943 & 0,739 & 0,973 & 0,970 \\
\hline Dukungan sosial $\left(\mathrm{Y}_{1.2}\right)$ & 0,801 & & & \\
\hline Situasi rumah, sosial, dan pekerjaan $\left(\mathrm{Y}_{1.3}\right)$ & 0,899 & & & \\
\hline Beban Kerja $\left(Y_{1.4}\right)$ & 0,933 & & & \\
\hline Lingkungan kerja $\left(\mathrm{Y}_{1.5}\right)$ & 0,936 & & & \\
\hline \multicolumn{5}{|l|}{ Coping $\left(\mathrm{Y}_{2}\right)$} \\
\hline Emotion focus coping $\left(\mathrm{Y}_{2.1}\right)$ & 0,953 & 0,667 & 0,969 & 0,966 \\
\hline Problem focused coping $\left(\mathrm{Y}_{2.2}\right)$ & 0,943 & & & \\
\hline \multicolumn{5}{|l|}{ Subjective Well Being $\left(\mathrm{Y}_{3}\right)$} \\
\hline Penerimaan Diri (Self Acceptance) $\left(\mathrm{Y}_{3.1}\right)$ & 0,948 & 0,685 & 0,978 & 0,976 \\
\hline $\begin{array}{l}\text { hubungan baik dengan orang lain (positive } \\
\text { relations with other) }\left(\mathrm{Y}_{3.2}\right)\end{array}$ & 0,934 & & & \\
\hline Autonom $\left(\mathrm{Y}_{3.3}\right)$ & 0,937 & & & \\
\hline $\begin{array}{l}\text { (penguasaan lingkungan (environmental } \\
\text { mastery) }\left(\mathrm{Y}_{4}\right)\end{array}$ & 0,925 & & & \\
\hline tujuan hidup (purpose in life) $\left(\mathrm{Y}_{5}\right)$ & 0,882 & & & \\
\hline pertumbuhan diri (personal growth) $\left(\mathrm{Y}_{6}\right)$ & 0,882 & & & \\
\hline
\end{tabular}

Catatan: *) indikator valid, apabila outer loadings $\geq 0,60$

$* *)$ discriminant validity baik, apabila AVE $>0,5$

**) indikator reliabel, apabila composite reliability dan cronbach alpha $\geq 0,70$

\section{Evaluasi Model Struktural (Inner Model)}

Model struktural dievaluasi dengan melihat $Q^{2}$ predictive relevance model yang mengukur seberapa baik nilai observasi dihasilkan oleh model. $Q^{2}$ didasarkan pada koefisien determinasi $\left(\mathrm{R}^{2}\right)$ seluruh variabel endogen, dalam model ini ada 3 variabel endogen, yaitu stres kerja, coping, subjective well being. Besaran $\mathrm{Q}^{2}$ memiliki nilai dengan rentang $0<\mathrm{Q}^{2}<1$, semakin mendekati nilai 1 berarti model semakin baik.

Koefisien determinasi $\left(\mathrm{R}^{2}\right)$ masingmasing variabel endogen ditampilkan pada Tabel 2 sebagai berikut.

Tabel 2

Nilai R-squareVariabel Endogen

\begin{tabular}{lc}
\hline \multicolumn{1}{c}{ Konstruk } & R-square \\
\hline Stres Kerja $\left(\mathrm{Y}_{1}\right)$ & 0,010192 \\
Coping $\left(\mathrm{Y}_{2}\right)$ & 0,439157 \\
Subjective Well Being $\left(\mathrm{Y}_{3}\right)$ & 0,719710 \\
\hline Sumper
\end{tabular}

Sumber: data primer diolah, 2017

Berdasarkan nilai $R$-square dapat dihitung $Q$-square sebagai berikut:

$\mathrm{Q}^{2} \quad=1-\left(1-\left(\mathrm{R}_{1}\right)^{2}\right)\left(1-\left(\mathrm{R}_{2}\right)^{2}\right)\left(1-\left(\mathrm{R}_{3}\right)^{2}\right)$ 


$$
\begin{aligned}
& =1-(1-0,10192)(1-0,439157)(1-0,719710) \\
& =1-0,1555965155 \\
& =0,844403484
\end{aligned}
$$

Dari hasil perhitungan tersebut didapat nilai $\mathrm{Q}^{2}$ sebesar 0,8444 sehingga dapat disimpulkan bahwa goodness of fit model struktural sangat baik. Hal ini juga dapat diartikan bahwa informasi yang terkandung dalam data, $84,44 \%$ dapat dijelaskan oleh model, sementara sisanya $14,46 \%$ dijelaskan oleh error dan variabel lain yang tidak dimasukkan dalam model.

\section{Hasil Pengujian Hipotesis}

Pengujian hipotesis dilakukan dengan $t$ test pada masing-masing jalur pengaruh variabel secara parsial. Hasil uji koefisien path pada setiap jalur disajikan pada Tabel 3 berikut. Berdasarkan hasil yang disajikan pada Tabel 3, maka dapat dijelaskan sebagai berikut.

Pertama, Pengaruh konflik peran terhadap subjective well being. Berdasarkan data yang ada didapat nilai koefisien jalur pengaruh konflik peran terhadap subjective well being sebesar $-0,658$, dengan nilai $t$ statistik sebesar 8,070 > 1,96. Maka dapat dikatakan konflik peran berpengaruh negatif dan signifikan terhadap subjective well being. Hasil ini menunjukkan hipotesis pertama $\left(\mathrm{H}_{1}\right)$ bahwa konflik peran berpengaruh negatif dan signifikan terhadap subjective well being, terdukung.

Kedua, Pengaruh konflik peran terhadap stres kerja. Dari data pada Tabel 3 diketahui nilai koefisien jalur sebesar 0,101 dengan $\mathrm{t}$ statistik sebesar 1,136 < 1,96. Maka dapat dikatakan pengaruh konflik peran terhadap stres kerja tidak signifikan. Hal ini menunjukkan bahwa hipotesis kedua $\left(\mathrm{H}_{2}\right)$ yang menyatakan pengaruh konflik peran positif signifikan terhadap stres kerja tidak terdukung, sehingga semakin tinggi atau rendah konflik peran maka tidak mempengaruhi tinggi rendahnya stres kerja.

Tabel 3

Path Coefficients

\begin{tabular}{lccl}
\hline Korelasi antar variabel & $\begin{array}{l}\text { Koefisien } \\
\text { jalur }\end{array}$ & t-statistik & Keterangan \\
\hline Konflik peran $\rightarrow$ Subjective well being & $-0,658$ & 8,070 & Signifikan \\
Konflik peran $\rightarrow$ Stres Kerja & 0,101 & 1,136 & Non signifikan \\
Stres Kerja $\rightarrow$ subjective well being & $-0,052$ & 1,447 & Non signifikan \\
Konflik peran $\rightarrow$ Coping & $-0,663$ & 12,286 & Signifikan \\
Coping $\rightarrow$ subjective well being & 0,246 & 3,074 & Signifikan \\
\hline $\begin{array}{l}\text { Konflik peran } \rightarrow \text { Subjective well being } \\
\text { (tanpa melibat variable mediasi-stres }\end{array}$ & $-0,827$ & 20,61 & Signifikan \\
kerja) & & & \\
\hline $\begin{array}{l}\text { Konflik peran } \rightarrow \text { Subjective well being } \\
\text { (tanpa melibat variable mediasi- }\end{array}$ & $-0,826$ & 20,73 & Signifikan \\
Coping) & & & \\
Sumber: Data primer diolah, 2017 & & & \\
\hline
\end{tabular}

Ketiga, Pengaruh konflik peran terhadap coping, diperoleh nilai koefisien jalur sebesar -0,663 dengan $t$ statistik $12.286>1,96$ sehingga dapat diartikan konflik peran berpengaruh negatif dan signifikan terhadap coping. Hasil ini menunjukkan bahwa hipotesis ketiga $\left(\mathrm{H}_{3}\right)$ yang berbunyi konflik peran berpengaruh negatif dan signifikan 
terhadap coping terdukung. Hasil ini juga dapat berarti semakin tinggi konflik peran maka coping juga semakin buruk.

Keempat, Pengaruh stres kerja terhadap subjective well being, nampak nilai koefisien jalur sebesar -0,052 dengan $\mathrm{t}$ statistik 1,447 < 1,96. Maka dapat dikatakan stres kerja berpengaruh negatif, terhadap subjective well being, tetapi tidak signifikan. Hal ini menunjukkan bahwa hipotesis keempat $\left(\mathrm{H}_{4}\right)$ yaitu, stres kerja berpengaruh negatif dan signifikan terhadap subjective well being tidak terdukung. Peningkatan stres kerja tidak berpengaruh pada baik atau buruknya subjective well being.

Kelima, Uji pengaruh coping terhadap subjective well being, didapat nilai koefisien korelasi sebesar 0,246 dengan $\mathrm{t}$ statistik 3,074 $>1,96$, maka dapat dikatakan ada pengaruh coping terhadap subjective well being. Hal ini menunjukkan bahwa hipotesis kelima $\left(\mathrm{H}_{5}\right)$ yang menyatakan pengaruh coping positif signifikan terhadap subjective well being terdukung, sehingga semakin baik coping maka semakin baik subjective well being yang dimiliki.

\section{Hasil Pengujian Mediasi}

Dengan memperhatikan hasil koefisien jalur seperti tersaji pada tabel 3, maka dapat dijelaskan efek mediasi sebagai berikut.

a. Efek mediasi stres kerja pada pengaruh konflik peran terhadap subjective well being. Berdasarkan data pada tabel 3, diketahui pengaruh konflik peran terhadap variabel subjective well being pada model dengan melibatkan variabel stres kerja adalah signifikan; efek konflik peran terhadap subjective well being tanpa melibatkan stres kerja, tidak signifikan; variabel konflik peran terhadap stres kerja, tidak signifikan; dan efek stres kerja terhadap subjective well being, tidak signifikan, maka dapat disimpulkan bahwa stres kerja tidak memediasi pengaruh konflik peran terhadap subjective well being. Dengan demikian, maka hipotesis 6 bahwa stres kerja memediasi pengaruh konflik peran terhadap subjective well being, tidak terdukung.

b. Efek mediasi coping, pada pengaruh konflik peran terhadap subjective well being. Dengan memperhatikan hasil pada Tabel 3, ternyata efek konflik peran te-r hadap subjective well being pada model dengan melibatkan variabel coping adalah signifikan; efek konflik peran terhadap subjective well being tanpa melibatkan coping, signifikan; efek konflik peran terhadap coping, signifikan; dan efek coping terhadap subjective well being signifikan, maka hal ini membuktikan bahwa coping sebagai partial mediation pada pengaruh konflik peran terhadap subjective well being. Temuan ini menunjukkan hipotesis 7 bahwa coping memediasi pengaruh konflik peran terhadap subjective well being terdukung.

\section{Pembahasan}

Pengaruh Konflik Peran terhadap Subjective Well Being

Hasil analisis menunjukkan bahwa konflik peran berpengaruh negatif signifikan terhadap subjective well being. Hasil ini dapat diartikan bahwa semakin tinggi konflik peran yang dialami perawat RSU Puri Raharja maka semakin buruk subjective well being mereka, begitu juga sebaliknya, jika semakin rendah konflik peran yang terjadi pada diri perawat maka subjective well being akan semakin baik. Hal ini didukung dengan hasil deskripsi variabel, di mana konflik peran yang dirasakan perawat RSU Puri Raharja ternyata dalam kategori sedang, sementara subjective well being perawat adalah dalam katagori baik.

Hal ini dapat terjadi karena konflik peran dari dimensi work family conflict dengan beberapa indikator, tergolong rendah. Dari ketersediaan waktu, mereka masih memiliki waktu akhir pekan bersama keluarga. Hal ini juga karena dukungan keluarga, di mana anggota keluarga tidak mengeluh dengan terbatasnya waktu bersama keluarga karena pekerjaan mereka. Selain dukungan keluarga, lingkungan sosial 
pun ternyata secara tidak langsung mendukung, dimana pengenaan sanksi tidak terlalu memberatkan serta kegiatan-kegiatan sosial yang dilakukan sebenarnya tidak terlalu menghambat pekerjaan di kantor.

Temuan ini berdampak pada tingginya dimensi "hubungan baik dengan orang lain" pada subjective well being yang menyumbang tingginya nilai subjective well being, namun di sisi lain, tingginya konflik antara pekerjaan dan kegiatan sosial menjadi penyebab utama terjadinya konflik peran perawat RSU Puri Raharja dengan jarang mengambil cuti disebabkan sulitnya mengambil cuti dan jarangnya perawat RSU Puri Raharja untuk menolak atau enggan dalam melaksanakan perintah kelihan banjar dalam melaksanakan tanggung jawab tentu menambah beban dan tanggung jawab mereka diluar tanggung jawab dalam pekerjaan. Hal ini mempengaruhi rendahnya dimensi penguasaan lingkungan pada subjective well being perawat. Mereka beranggapan mereka sering merasa kelelahan ketika harus mengurus pekerjaan, merasa kelelahan mengurus keluarga, dan kelelahan mengurus kegiatan sosial.

Hasil tersebut sesuai dengan penelitian terdahulu yaitu Kinnunen dan Mauno (1998); Vallone dan Donaldson (2001); Koyuncu et al. (2012) yang menyimpulkan bahwa adanya pengaruh negatif dan siginifikan konflik peran terhadap subjective well being. Hasil yang sejalan juga ditunjukkan dari penelitian lainnya yang menyebutkan konflik peran dapat memicu rendahnya well being yang dimiliki individu (Panatik et al., 2011; Koyuncu et al., 2012; Sianturi dan Zulkarnain, 2013).

\section{Pengaruh Konflik Peran terhadap Stres Kerja}

Hasil pengujian hipotesis menunjukkan bahwa konflik peran tidak signifikan berpengaruh terhadap stres kerja. Hasil ini didukung dengan data empirik, di mana hasil penelitian menunjukkan konflik peran yang dirasakan perawat tergolong sedang, demikian pula halnya dengan stres kerja yang sedang pula. Hasil ini menunjukkan bahwa tinggi rendahnya konflik peran yang dirasakan perawat RSU Puri Raharja tidak berpengaruh nyata terhadap tinggi rendahnya stres kerja mereka.

Konflik peran yang dirasakan perawat yang tergolong sedang terutama nampak dari dimensi konflik antara pekerjaan dan keluarga, yang dalam hal ini dukungan keluarga yang besar, terbukti dari anggota keluarga yang tidak banyak mengeluh, karena para perawat ini berupaya mengatur waktu untuk bisa bersama keluarga. Dalam hubungannya dengan stres kerja perawat, ternyata stres kerja yang dirasakan masih tergolong sedang, terutama dilihat dari dimensi situasi rumah, sosial, dan pekerjaan. Dalam kaitan ini perawat merasa bahwa beban kerja tidak menghalangi waktu untuk keluarga, serta adanya penghargaan atau pengertian dari keluarga atas pekerjaan yang dilakukan, sehingga kondisi ini dapat meredam stres kerja.

Faktor usia perawat juga dapat menjelaskan hasil ini. Mengingat bahwa perawat RSU Puri Raharja rata-rata berusia sekitar 3040 tahun sehingga mereka berada pada masa usia dewasa tengah atau middle adulthood. Pada usia ini individu akan cenderung dapat mengatasi sumber stres dengan lebih baik dibandingkan rentang usia lainnya. Mereka dianggap memiliki kemampuan yang lebih baik mengubah lingkungan stressor dan berusaha untuk menerima keadaan yang tidak dapat diubah (Lachman, 2004 dalam Papalia et al., 2009). Hal ini dapat menunjukkan bahwa perawat RSU Puri Raharja telah mampu mengatasi sumber stres yaitu konflik dan mampu mengubah sumber masalah sehingga dapat menerima stressor dengan lebih baik.

Selanjutnya pada usia middle adulthood pula mereka cenderung ingin lebih produktif dalam berkontribusi pada pekerjaan dan masyarakat memiliki keinginan untuk cenderung terlibat dalam segala hal yang menyangkut anak dan keluarga mereka (Papalia et al., 2009). Temuan ini menjelaskan bahwa walaupun para perawat RSU Puri 
Raharja mengalami konflik antara pekerjaan dan keluarga dan konflik antara pekerjaan dan sosial namun mereka menikmati konflik tersebut karena adanya keinginan untuk terlibat secara aktif dan produktif pada tiga tanggungjawab tersebut. Hasil penelitian ini sejalan dengan penelitian terdahulu yang menyebutkan bahwa konflik peran dapat memicu tingginya intensitas stres yang dirasakan individu yang bekerja (Jamadin et al., 2005; Delina dan Raya, 2013; Ul-Ain et al.,2013).

\section{Pengaruh Konflik Peran terhadap Coping}

Hasil analisis menunjukkan bahwa konflik peran berpengaruh negatif dan signifikan terhadap coping. Hasil ini didukung dengan data empirik, di mana konflik peran yang dirasakan perawat dalam intensitas sedang, diikuti dengan tingginya coping perawat RSU Puri Raharja. Hal ini dapat diartikan bahwa ketika perawat ini mengalami konflik peran yang rendah maka coping mereka semakin baik.

Hal ini dikarenakan rendahnya work family conflict, dalam hal mana para perawat RSU Puri Raharja merasakan adanya dukungan keluarga atas pekerjaan yang dilakukan. Selain itu waktu akhir pekan tetap mereka dapatkan untuk berkumpul bersama keluarga. Rendahnya dimensi work family conflict ini diikuti dengan tingginya dimensi dan indikator pada coping. Adanya dukungan dari keluarga ketika menghadapi konflik memberikan nilai yang tinggi terhadap kesempatan perawat untuk berbicara tentang yang dirasakan pada orang lain walaupun bukan untuk mencari solusi. Selain itu pemecahan masalah yang sama baik di kantor dengan di keluarga atau di kantor dengan kegiatan sosial, dapat meningkatkan kemampuan perawat untuk membuat rencana matang dalam menyelesaikan masalah serta dapat memahami masalah dari berbagai sudut padang, sehingga meningkatkan coping yang dimiliki. Hasil penelitian ini sejalan dengan penelitian Vashchenko et al. (2007) yang menyebutkan ada korelasi yang signifikan antara role conflict dengan coping. Selain itu hasil ini juga sejalan dengan penelitian Aazami et al.(2015), yang menyebutkan bahwa konflik peran yang rendah mampu memunculkan problem focused coping. Hasil penelitian ini didukung penelitian terdahulu dimana konflik peran memiliki korelasi yang signifikan terhadap coping (Vashchenko et al., 2007; Aazami et al., 2015).

\section{Pengaruh Stres Kerja terhadap Subjective Well Being}

Dari hasil pengujian hipotesis terbukti bahwa stres kerja tidak berpengaruh signifikan terhadap subjective well being. Hal ini didukung dengan data empirik di mana tingkat stres kerja yang dialami para perawat ini tergolong sedang, namun subjective well being mereka ternyata baik. Hasil ini mengindikasikan walaupun ada kondisi yang memicu terjadinya stres namun tidak berdampak nyata dengan tingat kesejahteraan dirinya, dalam hal ini subjective well being mereka tetap tinggi.

Dimensi dukungan sosial salah satu dimensi stres kerja memang tergolong tinggi, yang memiliki arti bahwa stres kerja perawat RSU Puri Raharja dipicu oleh dukungan sosial yang rendah. Terkadang mereka tidak mendapat penghargaan atas kinerja yang baik dan ada kesulitan mengemukakan masalah menjadi alasannya. Dimensi lain yaitu lingkungan kerja yang kurang mendukung, di mana para perawat ini merasa bahwa karir yang sulit berkembang dan terbatasnya kesempatan untuk mengembangkan kemampuan juga menjadi pemicu stres kerja, namun, hal tersebut tidak berdampak nyata pada subjective well being, dengan melihat dimensi penerimaan diri yang memiliki nilai rata-rata tinggi. Walaupun keadaan-keadaan pemicu stres kerja yang telah dipaparkan sebelumnya tinggi, namun perawat tetap bangga dengan apa yang telah dicapai. Mereka juga dapat menerima semua kekurangan yang ada dalam hidupnya dan tidak menyesali keputusan-keputusan yang telah diambil. 
Selain itu, bila dihubungkan dengan karakteristik individu yaitu usia perawat RSU Puri Raharja yang berada dalam rentang midlle adulthood, cenderung mampu menangani stres yang dialami. Pada rentang usia ini pula, individu dianggap telah memiliki well being yang stabil dan memiliki mental yang sehat, sehingga subjective well being mereka tetap tinggi. Selain rentang usia, dalam hal ini ada indikasi prediktor lain yang mempengaruhi well being yaitu locus of control. Menurut Griffin (2014), ada perbedaan pengaruh antara locus internal dan locus eksternal terhadap intensitas well being individu, sehingga dapat diartikan locus internal memengaruhi secara positif subjective well being.

\section{Pengaruh Coping terhadap Subjective Well Being}

Hasil analisis menunjukkan bahwa coping berpengaruh positif signifikan terhadap subjective well being. Hasil ini memberi arti, dengan semakin baik coping perawat maka subjective well being mereka juga semakin baik. Hal ini dapat dilihat dari kondisi coping mereka dalam kategori baik dan subjective well being juga tergolong dalam baik.

Coping yang baik terutama dipicu dengan tingginya nilai dimensi problem focused coping, yang dalam hal ini para perawat mencoba memahami masalah dari sudut pandang berbeda, mengingatkan diri untuk menjadi orang yang lebih baik, sehingga mendorong pertumbuhan diri, dengan memandang bahwa hidup adalah proses belajar, sehingga kemampuan perawat Puri Raharja untuk memotivasi diri menjadi lebih baik berdampak pada tingginya subjective well being. Selain itu para perawat juga merasa lebih baik dengan menghabiskan waktu sendiri, masalah merupakan tanggung jawab pribadi yang harus diselesaikan sendiri secara langsung meningkatkan pula autonomi mereka sehingga subjective well being perawat menjadi baik. Mereka dapat melaksanakan segala tindakan atas kemampuan dan kemauan sendiri.
Hasil penelitian ini didukung penelitian sebelumnya bahwa strategi coping berdampak pada intensitas well being (Van Harreveld et al., 2007; Picken, 2012; Rodriguez et al.,2015).

\section{Peran Stres Kerja dalam Memediasi Hubungan Konflik Peran dengan Subjec- tive Well Being}

Hasil analisis data memberi petunjuk bahwa pengaruh konflik peran terhadap stres kerja dan pengaruh stres kerja terhadap subjective well being sama-sama menghasilkan hubungan yang tidak signifikan, sehingga dapat dikatakan stres kerja bukan pemediasi pengaruh konflik peran terhadap subjective well being. Temuan ini menunjukkan bahwa tinggi rendahnya tingkat stres kerja tidak berdampak pada hubungan konflik peran dengan subjective well being. Hal ini dikarenakan konflik peran yang dirasakan perawat RSU Puri Raharja tidak begitu membuat mereka stres dalam pekerjaaan. Stres kerja yang dirasakan terutama karena faltor perilaku individu dalam menghadapi pasien, bukan karena konflik peran. Selanjutnya intensitas stres kerja yang dirasakan perawat tidak begitu tinggi, sehingga subjective well being mereka tetap baik. Alasan lainnya, juga karena usia perawat RSU Puri Raharja dalam rentang midlle adulthood yang cenderung mampu menangani stres yang dialami, sehingga tidak begitu memengaruhi subjective well being mereka.

Dalam kaitan ini, para perawat RSU Puri Raharja rata-rata berusia sekitar 30-40 tahun, yang mana pada usia ini individu akan cenderung dapat mengatasi sumber stres dengan lebih baik dibandingkan rentang usia lainnya dan dianggap telah memiliki well being yang stabil dan memiliki mental yang sehat.

\section{Peran Coping Memediasi Hubungan Konflik Peran dengan Subjective Well Being}

Hasil analisis menemukan bahwa konflik peran berpengaruh signifikan terhadap 
subjective well being, konflik peran berpengaruh signifkan terhadap coping, dan coping berpengaruh signifikan terhadap subjective well being. Maka dapat dikatakan bahwa coping sebagai partial mediation pengaruh konflik peran terhadap subjective well being. Hal ini mengindikasikan bahwa baik coping dan konflik peran menjadi faktor penting menentukan subjective well being pada perawat RSU Puri Raharja, sehingga strategi coping yang tepat akan membantu mereka untuk mengurangi dampak konflik peran yang dialami sehingga dapat tetap meningkatkan subjective well being mereka.

\section{SIMPULAN DAN SARAN \\ Simpulan}

Berdasarkan pembahasan hasil penelitian ini maka dapat disimpulkan sebagai berikut: 1) Konflik peran berpengaruh negatif dan signifikan terhadap subjective well being. Hal ini menunjukkan bahwa jika konflik peran yang dialami seseorang meningkat, maka subjective well being mereka akan menurun. 2) Konflik peran tidak berpengaruh signifikan terhadap stres kerja. Hal ini dikarenakan adanya faktor-faktor lain seperti rentang usia, keadaan lingkungan kerja, sehingga konflik peran yang terjadi tidak berdampak nyata atau signifkan pengaruh terhadap stres kerja. 3) Konflik peran berpengaruh negatif dan signifikan terhadap problem coping. Hal ini memiliki makna bahwa adanya peningkatan konflik peran yang dialami dapat menurunkan kemampuan problem coping yang dimiliki individu. 4) Stres kerja tidak berpengaruh signifkan terhadap subjective well being. Hal ini dikarenakan adanya faktor rentang usia middle adulthood yang memengaruhi subjective well being lebih stabil di usia middle adulthood. 5) Coping berpengaruh positif signifikan terhadap subjective well being. Hal ini dapat dimaknai adanya peningkatan kemampuan problem coping dapat meningkatkan subjective well being pada individu. 7) Coping terbukti mampu memediasi pengaruh konflik peran terhadap subjective well being. Hal ini dimaknai bahwa tanpa adanya coping, konflik peran dapat memengaruhi subjective well being, namun kehadiran coping sebagai mediator dapat menurunkan pengaruh konflik peran terhadap subjective well being sehingga subjective well being dapat ditingkatkan.

\section{Keterbatasan dan Saran}

Berdasarkan penelitian yang dilakukan didapat beberapa keterbatasan pada penelitian ini antara lain: 1) Penelitian ini hanya dilakukan pada satu institusi yaitu rumah sakit umum Puri Raharja, sehingga penting pada penelitian di masa datang memperkaya responden dari rumah sakit lain dengan akreditasi yang berbeda atau menggunakan industri lain yang berhubungan dengan pelayanan seperti pariwisata, dan perbankan; 2) Penelitian ini hanya mengambil responden wanita, sehingga untuk penelitian selanjutnya dapat mengembangkan responden laki-laki dan wanita sehingga memperkaya temuan dari penelitian. Penelitian selanjutnya juga bisa mengembangkan penelitian dengan membedakan usia, mengingat adanya perbedaan perkembangan pada setiap tahapan usia; 3) Penelitian ini tidak dapat membuktikan peran stres kerja dalam memediasi pengaruh konflik peran terhadap subjective well being, sehingga pada penelitian selanjutnya hal ini dapat diteliti kembali atau mengubah model dari penelitian.

\section{DAFTAR PUSTAKA}

Aazami, S., K. Shamsuddin, dan S. Akmal. 2015. Examining Behavioural Coping Strategies as Mediators between WorkFamily Conflict and Psychological Distress. The Scientific World Journal 2015: 1-7.

Alves, S. L. 2005. A Study of Occupational Stress, Scope of Practice, and Collaboration in Nurse Anesthestists Practicing in Anesthesia Care Team Setting. AANA Journal 73(6): 443-452.

Barron, R. G., I. M. Castilla, M. Casullo, dan J. B. Verdu. 2002. Relacion Entre Estilos 
y Estrategias de Afrontamiento y Bienestar Pscologico en Adolescentes. Psicothema 14(2): 363-368.

Bell, A. S., D. Rajendran, dan S. Theiler. 2012. Job Stress, Wellbeing, Work-Life Balance and Work-Life Conflict among Australian Academics. Electronic Journal of Applied Psychology 8(1): 25-37.

Carver, C. S., M. F. Scheier, dan J. K. Weintraub. 1989. Assesing Coping Strategies: a Theoretically Based Approach. Journal of Personality and Social Psychology 56(2): 267-283.

Churiyah, M. 2007. Pengaruh Konflik Peran (Role Conflict) terhadap Kepuasaan Kerja Perawat serta Komitmen pada Organisasi. Modernisasi 3(1): 43-53.

Delina, G. dan R. P. Raya. 2013. A Study on Work-Life Balance in Working Women. International Journal of Commerce, Business and Management 2(5): 274-282.

Diener, Ed. 2009. The Science of Well-being: the Collected Works of Ed Diener. Springer Science \& Business Media. USA.

Elfering, A., S. Grebner, N. K. Semmer, D. K. Freiburghaus, S. L. D. Ponte, dan I. Witschi. 2005. Chronic Job Stressors and Job Control: Effects on Event Related Coping Success and Well-Being. Journal of Occupational and Organizational Psychology 78(2): 237-252.

Elgar, K. dan A. Chester. 2007. The Mental Health Implication of Maternal Employment: Working versus at Home Mothering Identities. Australian e-Journal for the Advancement of Mental Health 6(1): 47-55.

Erlandsson, L. K. dan M. Eklund. 2006. Levels of Complexity in Patterns of Daily Occupations: Relationship to Women's Well-Being. Journal of Occupational Science 13(1): 27-36.

Fierro, C. dan J. A. Jimenez. 2002. Well Being, Personality Dimensions and Coping in Young People. Escritos de Psicologia 6: 8591.

Folkman, S. 1984. Personal Control and Stress and Coping Processes: A Theoretical Analysis. Journal of Personality and Social Psychology 46(4): 839-852.
Ghozali, I. dan H. Latan. 2015. Partial Least Squares Konsep, Teknik, dan Aplikasi Menggunakan Smartpls 3.0 untuk Penelitian Empiris. UNDIP. Semarang.

Griffin, D. P. 2014. Locus of Control and Psychological Well Being: Separating the Measurement of Internal and External Construct. Eastern Kentucky University Libraries Research Award for Undergraduates 3: 1-13.

International Labour Organization. 2014. Tren Sosial dan Ketenagakerjaan. Indonesia.

Jamadin, N., S. Mohamad, Z. Syarkawi, dan F. Noordin. 2015. Work Family Conflict and Stress: Evidence from Malaysia. Journal of Economic, Business and Management 3(2): 309-312.

Keyes, C. L. M. 2005. Mental Ilness and/or Mental Health? Investigating Axioms of the Complete State Model of Health. Journal of Consulting and Clinical Psycho$\log y$ 73(3): 539-548.

Kinnunen, U. dan S. Mauno. 1998. Antecedents and Outcomes of Work Family Conflict among Employed Women and Men in Finland. Human Relations 51(2): 157-177.

Koyuncu, M., R. J. Burke, L. Fiksenbaum. 2009. Work-Family Conflict among Turkish Managers: Potential Antecedents and Consequences. The Journal of Industrial Relations and Human Resources 11(1): 1-16.

Kurnia, N. P. 2015. The Impactof Stressat Workon Employee's Psychological Well-being in Jakarta. iBuss Management 3(2): 68-76.

Lennon, M. C. 1994. Women, Work, and Well-Being: The Importance of Work Conditions. Journal of Health and Social Behavior 35(3): 235-247.

Leung, M. Y., J. Sham, dan Y. S. Chan. 2007. Adjusting Stressors-job Demand Stress in Preventing Rustout/Burnout in Estimators. Surveying and Built Environment 18(1): 17-26.

Lo, S., R. Stone, dan C. W. Ng. 2003. Work Family Conflict and Coping Strategies 
Adopted by Female Married Professionals in Hongkong. Women in Management Review 18(4): 182-190.

Luthans, F. 2006. Organizational Behavior. Ninth Edition. McGraw Hill. New York.

Malek, M. D. A., K. Mearns, dan R. Flin. 2010. Stress and Psychological Well Being in UK and Malaysian Fire Fighters. Cross CulturalManagement: an International Journal 17(1): 50-61.

Munthe, H. M. 2003. Perkembangan Status dan Peranan Wanita Indonesia. USU Digital Library 1-8.

Nilakusumawati, D. P. E. dan M. Susilawati. 2011. Studi Faktor-Faktor yang Mempengaruhi Wanita Bekerja di Kota Denpasar. Piramida VIII(1): 26-31.

Page, K. M. dan D. A. V. Brodrick. 2009. The 'What', 'Why', and 'How' of Employee Well Being: a New Model. Social Indicators Research 90(3): 441-458.

Panatik, S. A., S. K. Z. Badri, A. Rajab, H. A. Rahman, dan I. M. Shah. 2011. The Impact of Work Family Conflict on Psychological Well Being among School Teachers in Malaysia. Procedia-Social and Behavioral Sciences 29: 1500-1507.

Paramartha, I. G. N. B. 2015. Landasan Yuridis dan Makna Pengukuhan AwigAwig Desa Pakraman oleh Bupati/ Walikota.Tesis. Program Pascasarjana Universitas Udayana. Denpasar.

Bourgault, P., S. Lavoie, E. P. Savoie, M. Gregoire, C.Michaud, E. Gosselin, dan C. C. Johnston. 2015. Relationship between Empathy and Well Being among Emergency Nurses. Journal of Emergency Nursing 41(4): 323-328.

Papalia, D. E., S. W. Olds, dan R. D. Feldman. 2009. Human Development. Eleven Edition. Mcgraw-Hill International Edition. USA.

Peraturan Menteri Pemberdayaan Perempuan dan Perlindungan Anak Republik Indonesia. 2015. Menteri Pemberdayaan Perempuan dan Perlindungan Anak Republik Indonesia. Jakarta.

Picken, J. 2012. The Coping Strategies, Adjusment and Well Being of Male Inmates in the Prison Environment. Internet Journal of Criminology(2012): 1-29.

Powell, G. N. dan J. H. Greenhaus. 2006. Is The Opposite of Positive Negative?: Untangling the Complex Relationship between Work-Family Enrichment and Conflict. Career Development International 11(7): 650-659.

Rodriguez, T. M., J. C. Melendez-Moral, P. V. Segui, dan A. S. Galan. 2015. Coping Strategies as Predictors of Well Being in Youth Adult. Social Indicators Research 122(2): 479-489.

Ryff, C. D. dan C. L. M. Keyes. 1995. The Structure of Psychological Well Being Revisited. Journal of Personality and Social Psychology 69(4): 719-727.

Sahu, F. M. dan S. Rath. 2003. Self Efficacy and Wellbeing in Working and Nonworking Women: The Moderating Role of Involvement. Psychology and Developing Societies 15(2): 187-198.

Sianturi, M. M. dan Zulkarnain. Analisis Work Family Conflict terhadap Kesejahteraan Psikologis Pekerja. Jurnal Sains dan Praktik Psikologi 1(3): 207-215.

Sudantra, I. K. 2011. Tri Semaya Hukum Adat Bali: Potret Perkembangan Hak Perempuan Bali dalam Hukum Keluarga. http://sudantra.blogspot.co.id/2011/12/ gender-dalam-hukum-adat-bali.html. Diakses tanggal 15 Desember 2016.

Srimathi, N. L. Dan S. K. K. Kumar. 2010. Psychological Well Being of Employed Women Across Different Organisations. Journal of the Indian Academy of Applied Psychology 36(1): 89-95.

Taylor, S. E., L. A. Peplau, dan D. O. Sears. 2009. Psikologi Sosial. Edisi Keduabelas. Kencana Prenada Media Group. Jakarta.

Ul-Ain, Q., M. A. Khattak, dan N. Iqbal. 2013. Impact of Role Conflict on Job Satisfaction, Mediating Role of Job Stress in Private Banking Sector. Interdisciplinary Journal of Contemporary Research in Business 4(12): 711-722.

Vallone, E. J. G. dan S. I. Donaldson. 2001. Consequences of Work Family Conflict 
on Employee Well-Being over Time. Work E Stress 15(3): 214-226.

Van Harreveld, F., J. Van Der Pligt, L. Claassen, dan W. W. Van Dijk. 2007. Intimate Emotion Coping and Psychological and Physical Well Being. Criminal Justice and Behavior 34(5): 607-708.

Varma, R. dan N. Dhawan. 2006. Psycho Social Factors and Mental Health of Contemporary Indian Women. Psychological Studies 51(2/3): 171-177.

Vashchenko, M., E. Lambidoni, dan L. R. Brody. 2007. Late Adolescents'Coping Styles in Interpersonal and Intrapersonal Conflicts using the Narrative Disclosure.Clinical Social Work Journal 35(4): 245-255.

Williams, K. dan A. McGillicuddy-De Lisi. 2000. Coping Strategies in Adolescents. Journal of Applied Developmental Psychology 20(4): 537-549.
Xu, L. 2009. View on Work-family Linkage and Work-family Conflict Model. Inter- national Journal of Business and Management 4(12): 229-233.

Yang, N., C. C. Chen, J. Choi, dan Y. Zou. 2000. Source of Work-family Conflict: A Sino-U.S. Comparison of the Effects of Work and Family Demands. Academy of Management Journal 43(1): 113-123.

Yufiza. 2010. Peran Perempuan Bali. https:// gunungrata.wordpress.com/2010/05/10/per an-perempuan-bali/. Diakses tanggal 15 Desember 2016.

Yunus, J. M., B. Mahajar, dan A. Jumaat. 2011. Stress and Psychological Wellbeing of Government Officers in Malaysia. The Journal of Human Resource and Adult Learning 7(2): 40-50. 